\title{
THE REMARKABLE FROG EAR: IMPLICATIONS FOR VERTEBRATE HEARING
}

\author{
Andrew Bell
}

John Curtin School of Medical Research, Australian National University, Canberra, Australia

Corresponding author: Andrew Bell, John Curtin School of Medical Research, Australian National University, Canberra, ACT 2601, Australia, e-mail: andrew.bell@anu.edu.au

\begin{abstract}
Frogs, and related amphibians, are adapted to live in both air and water, and so good hearing in both mediums is required. The structure of the frog ear can therefore provide a useful perspective on how sound is sensed and the physical principles involved in hearing. This broad survey of the literature highlights two noteworthy aspects of the frog ear and brings them together into a single framework. First, the frog ear contains an arrangement of sensing cells which is difficult to understand: although they are meant to detect sound, the cells are hidden away in recesses and further shielded from incoming sound by a number of 'short-circuits' in the vibratory pathway. Second, there is the operculum, a moveable plate that fits into the oval window adjacent to the stapes and whose function remains controversial. Both these challenging features can be understood by noting that all sounds carry both pressure and displacement components, and that form and function can be matched by focusing on the pressure component, which to date has been largely overlooked. This paper proposes that the hair cells at the core of the system respond more sensitively to pressure than to displacement. Building on this property, the piston-like operculum, operated by the opercularis muscle, is put forward as a mechanism for adjusting the static hydraulic pressure within the otic capsule, in this way controlling the global sensitivity, or gain, of the sensing cells within. Both these hypotheses have wider implications for understanding hearing in vertebrates.
\end{abstract}

Key words: effective stimulus $\bullet$ pressure $\bullet$ displacement $\bullet$ operculum $\bullet$ hair cells $\bullet$ compressibility

\section{EL OÍDO EXTRAORDINARIO DE RANAS: CÓMO FUNCIONA EL OÍDO DE VERTEBRADOS}

\section{Resumen}

Las ranas y otros anfibios relacionados, están adaptados a la vida tanto en tierra como en agua, por lo que precisan de un buen oído en ambos entornos. La estructura de la oreja de una rana puede servir, entonces, como un ejemplo de la percepción del sonido y también un ejemplo de principios generales para la audición.

Este amplio estudio, basado en literatura, pone de relieve dos aspectos relevantes del oído de una rana y los combina en el mismo marco. En primer lugar, el sistema del oído de ranas está dotado de células sensoriales, que es difícil de entender. Aunque la función de estas células es la de detectar el sonido, están ocultas en el interior, y separadas además por una serie de 'cortocircuitos’ en la transmisión de vibraciones. En segundo lugar, en el oído de una rana se encuentra un tapón mucoso, es decir una placa móvil en la ventana oval, junto al estribo, cuya función no está del todo clara. Estas dos características curiosas pueden llevar a la conclusión, de que el sonido se transmite tanto a través del gradiente de presión, como y a través del movimiento oscilatorio. Esta forma y función se pueden combinar a través de la concentración en el gradiente de la presión, que hasta ahora ha sido varias veces ignorado.

Este trabajo sugiere que las células ciliadas auditivas en el centro del sistema responden de una manera más sensible a la presión que a las vibraciones. Basándonos en esta propiedad, el tapón mucoso que se asemeja a un pistón de un motor, que funciona gracias al músculo opercular, está representado como el mecanismo para una regulación de la presión hidráulica estática dentro de la cápsula del oído, controlando de esta forma la sensibilidad global o reforzamiento de las células sensoriales. Ambas hipótesis tienen un significado más amplio para la compresión de la audición en los vertebrados.

Palabras clave: estímulo efectivo • presión • desplazamiento • tapón mucoso • células ciliadas • compresibilidad 


\title{
НЕОБЫКНОВЕННОЕ УХО ЛЯГУШКИ: ФУНКЦИОНИРОВАНИЕ СЛУХА У ПОЗВОНОЧНЫХ ЖИВОТНЫХ
}

\begin{abstract}
Изложение
Лягушки, а также другие связанные с ними родством земноводные, приспособлены к жизни как на земле, так и в воде, поэтому у них должен быть хороший слух в этих двух средах. Строение уха лягушки может послужить как пример того, как восспринимается звук, и как пример широких принципов, касающихся слуха. Это обширное исследование на основании литературы подчеркивает два важные аспекты уха лягушки и сочитает их в те самые рамки. Во-первых, ухо лягушки имеет систему чувствительных клеток, которую тяжело понять. Хотя клетки должны обнаруживать звук, они глубоко спрятаны, кроме того, они отделены рядом "замыканий" на пути передачи колыбаний. Во-вторых, в ухе лягушки находится слизистая пробка, то есть подвижная плита в овальном окошке, прилегающая к слуховой косточке, функция которой неоднозначна. Эти две интересные черты могут вести к утверждению, что звуки перемещают как градиент давлений, та и колеблющееся движение. Эта форма и функция могут смешиваться путем концентрации на градиенте давления, который до сих пор был зачастую игнорирован. Настоящая работа предполагает, что слуховые клетки в центре системы отвечают более чувствительно на давление, че на колыбания. Базируя на этой особенности, слизистая пробка, напоминающая поршень двигателя и работающая благодаря оперкулярному мускулу, представленна в виде механизма для регулировки статического гидравлического давления внутри капсулы уха, таким способом контролируя общую чувствительность или усиление чувствительных клеток. Эти обе гипотезы имеют более широкое значение для понимания слуха у земноводных.
\end{abstract}

Ключевые слова: эффективный импульс • давление • перемещение • слизистая пробка • слуховые клетки • сжимаемость

\section{NIEZWYKŁE UCHO ŻABY: DZIAŁANIE SŁUCHU U KRĘGOWCÓW}

\section{Streszczenie}

Żaby, oraz inne spokrewnione z nimi płazy, są przystosowane do życia zarówno na lądzie jak i w wodzie, dlatego muszą mieć dobry słuch w obu tych środowiskach. Budowa ucha żaby może zatem posłużyć za przykład jak odbierany jest dźwięk i za przykład szerokich zasad dotyczących słuchu. To obszerne badanie na podstawie literatury podkreśla dwa ważne aspekty ucha żaby i łączy je w te same ramy. Po pierwsze, ucho żaby zawiera układ komórek zmysłowych, który jest trudny do zrozumienia. Mimo że komórki te mają wykrywać dźwięk, są one ukryte w głębi i dodatkowo odseparowane przez szereg 'zwarć' na drodze przenoszenia drgań. Po drugie, w uchu żaby znajduje się czop śluzowy, czyli ruchoma płytka w okienku owalnym przylegajaca do strzemiączka, której funkcja nie jest jednoznaczna. Obie te ciekawe cechy mogą prowadzić do stwierdzenia, że dźwięki przenoszą zarówno gradient ciśnień jak i ruch drgający. Ta forma i funkcja mogą się łączyć poprzez koncentrację na gradiencie ciśnieniowym, który dotąd był często pomijany. Niniejsza praca sugeruje, że komórki słuchowe w centrum systemu odpowiadają w sposób bardziej wrażliwy na ciśnienie niż drgania. Bazując na tej właściwości, czop śluzowy, który przypomina tłok w silniku, pracujący dzięki mięśniowi wieczkowemu, jest przedstawiony jako mechanizm do regulacji statycznego ciśnienia hydraulicznego wewnątrz kapsuły ucha, w ten sposób kontrolując ogólną czułość lub wzmocnienie komórek zmysłowych. Obie te hipotezy mają szersze znaczenie dla zrozumienia słuchu u kręgowców.

Słowa kluczowe: skuteczny bodziec • ciśnienie • przemieszczenie • czop śluzowy • komórki słuchowe • ściśliwość

\section{Background}

Frogs are remarkable creatures. Their transparent eggs grow in water until juvenile tadpoles, which are able to hear, hatch some time later. The tadpoles drastically change form and transmute into frogs, amphibians which can hear well on both land and in water [1].

Each species also has its own distinctive call, and their unique croaks can be as loud as $100 \mathrm{~dB}$ at $0.5 \mathrm{~m} \mathrm{[2].} \mathrm{At}$ the ear of the frog, of course, the intensity must be even louder, particularly as their ears connect to the back of the throat [3]. This arrangement suggests that the sensitivity of the ear must be damped down during vocalization, as happens in most animals, including humans. Some form of gain control is needed to prevent overload and enhance the dynamic range of hearing.

Unusually among animals that hear, the tympanum of the frog is located on the outside of the body, making it both visible and able to be touched (Figure 1). Movement through the environment must lead to contact with vegetation, and immersion in water must cause rapid changes in pressure. Moreover, the tympanum bulges out visibly whenever the frog croaks or swallows [4], and the tympanum has been observed to efficiently broadcast sound, enhancing the loudness of their call [5]. Some mechanism to accommodate pressure spikes is therefore expected. Frog ears have a feature unique to amphibians, a plate-like structure within the oval window called the operculum, which 


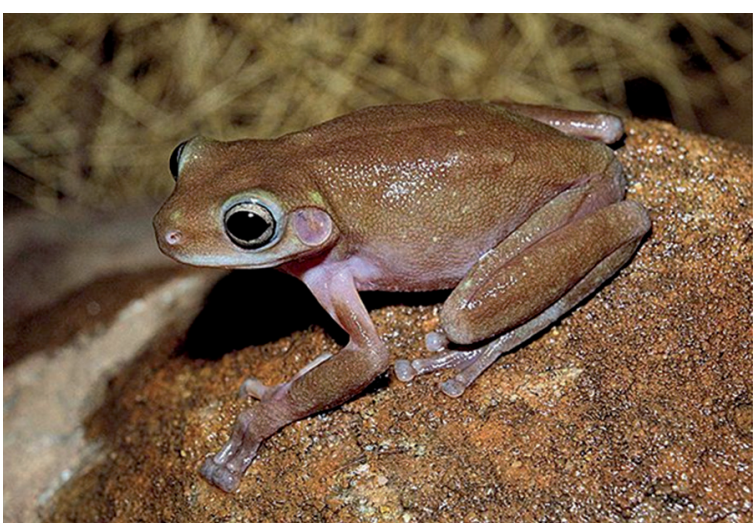

Figure 1. The cave frog, Litoria cavernicola, an Australian frog which, like many amphibians, has a distinctive tympanum visible behind its eye. Photo credit: Paul Doughty, Western Australian Museum

in turn is connected to a muscle, the opercularis muscle. Also remarkable, some frogs are "earless", in that they lack an external tympanum and might be considered anatomically deaf [6], yet the hearing of these frogs appears to be comparable in sensitivity and frequency range to species who do have a tympanum [4].

Other unusual features of frog hearing are that the ears are connected via the cranium [3], that the ears are often sexually dimorphic, that the round window and oval window exchange functions during metamorphosis from tadpole to adult [1], that some species can hear ultrasound [7], and that the males of some species of frogs grow small sponge-like masses on their tympanum during the mating season [8].

Most significantly, it is now known that the frog ear is an active device, so that hearing involves some energy-consuming process. Like the ear of humans, the frog ear emits otoacoustic emissions [9], features indicative of some sort of 'cochlear amplifier' at work, an amplifier whose mode of operation is still unknown. However, it is clear that otoacoustic emissions must derive from the sensing cells, which actively move in the course of detecting sound. Small quantities of sound emerge from the ear and can be detected with a sensitive microphone next to the tympanic membrane.

Otoacoustic emissions have revolutionized our understanding of how animals hear, and a key question is how the emissions are generated in frogs [10]. This paper takes the form of a literature synthesis in which the broad question of how the frog ear detects sound is surveyed, and a new model involving the detection of the pressure component of sound is proposed. The hypothesis is made that frogs hear by detecting the pressure component of a sound, a strategy which increases hearing sensitivity compared to the standard model in which only the displacement component is considered. The theory offers an explanation of anatomical features and relationships that are otherwise difficult to understand - the operculum in particular - and it offers a perspective on how otoacoustic emissions might be generated. This broad survey of the literature comes to the conclusion that frog ears and human ears might operate on similar physical principles.

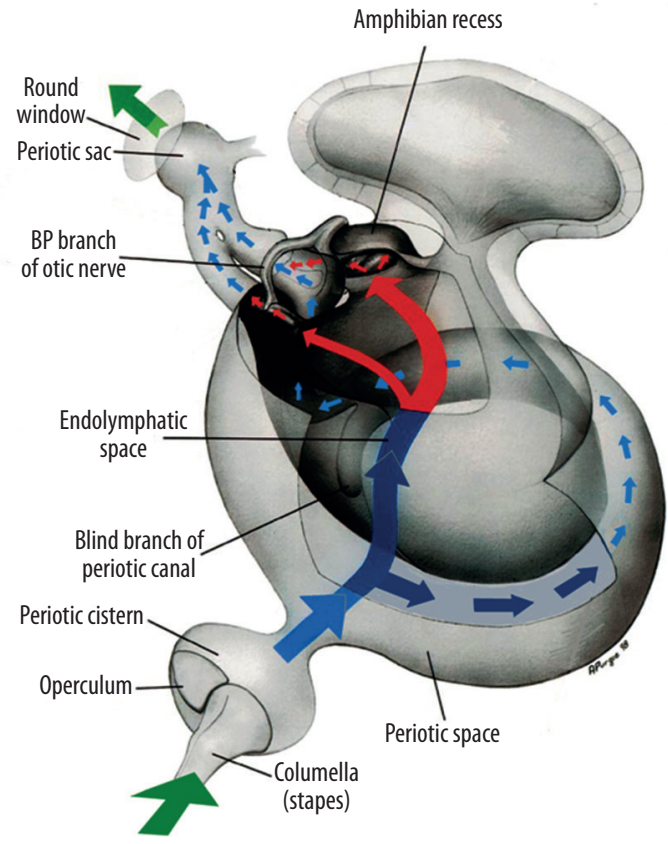

Figure 2. A perspective view of a frog inner ear showing the path a sound stimulus takes through the otic capsule. Sound enters the capsule (green arrow at bottom) through the oval window, which contains the stapes (also called the columella) and the operculum, and exits through the round window (green arrow at top). The blue path shows propagation through perilymph; the red path shows propagation through endolymph. The broken arrows represent puzzling "acoustic short-circuits" which appear to bypass the sensing cells (adapted from [11] and used with permission of Springer-Verlag)

\section{Anatomy of the frog ear, and the standard model of hearing}

The inner ear of a typical frog is shown in Figure 2. Its form resembles that of other vertebrates, essentially a bony otic capsule filled with fluid and containing numerous sensing cells. There are two windows, the oval window and the round window. Figure 2 is a perspective view showing the geometrical relationship of the major components. To aid understanding of the mechanics, Figure 3 is a two-dimensional diagram showing the two major groups of sensing cells, the amphibian papilla (AP) and the basilar papilla (BP), and adjoining anatomical compartments. The system is complex, naturally reflecting the term 'labyrinth', a name also applied to the mammalian inner ear.

\section{Acoustic pathways in frog hearing}

As in mammals, the inner ear of frogs senses both vibration and balance, all contained within a bony otic capsule filled with tissue, cartilage, perilymph, and endolymph. Vibration sensing is done with two patches of sensory cells within the capsule, the amphibian papilla (AP) and the basilar papilla (BP), both immersed in incompressible endolymph and surrounded by rigid bone. Sound is picked up by a tympanum at the surface of the body, transmitted 


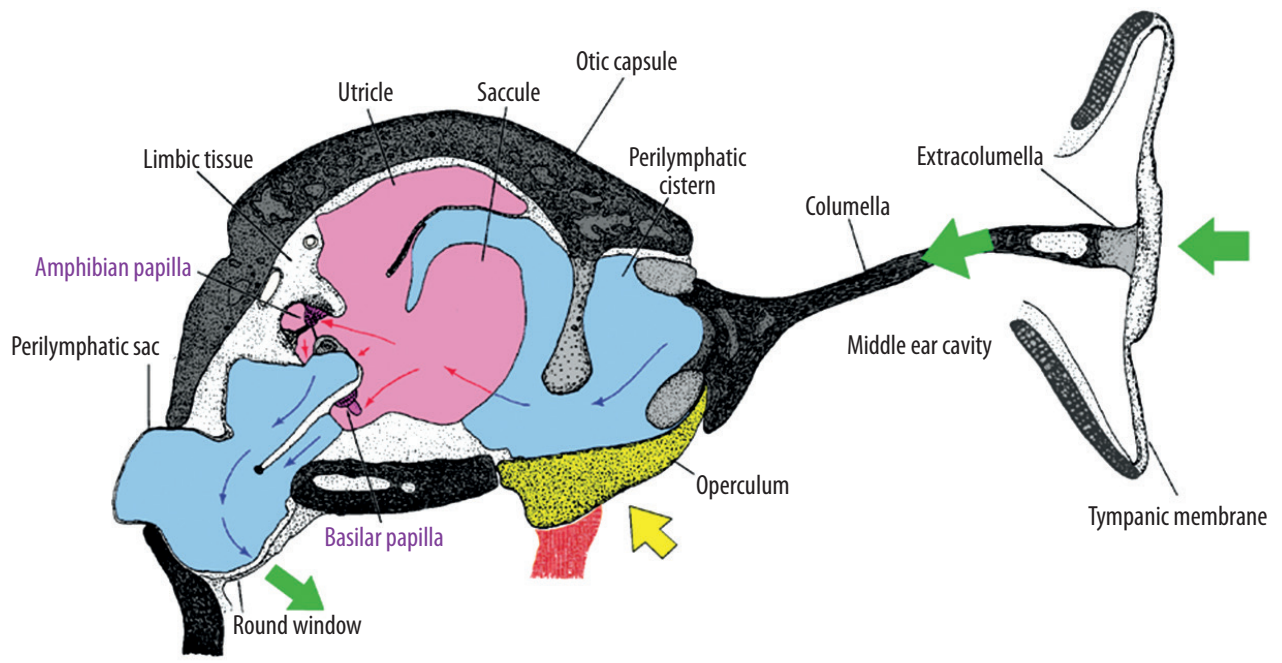

Figure 3. The otic capsule is a rigid bony structure (dark shading - bone) filled with incompressible fluids (endolymph - pink; perilymph - blue). Sound (green arrows) enters the capsule through the compliant oval window (containing columella and operculum) and exits through the compliant round window at bottom. Two patches of sensory cells (magenta) lie within the capsule, the amphibian papilla (AP) and the basilar papilla (BP). The figure is adapted from a drawing by Wever and the thin arrows follow the path of the displacement stimulus which he thought activated the AP and BP. The physics of the system is much simplified if the AP and/or the BP are actually pressure sensors, not displacement sensors. The columella, or stapes, can be seen to act like an oscillating plunger, generating an alternating hydraulic pressure throughout the capsule. The columella works against the compliance of the round window to generate an oscillating pressure field which extends throughout the capsule. In a related action, the opercularis muscle (red) forces the bony operculum (yellow) into the capsule, this time raising the static hydraulic pressure. Adapted with permission from E. G. Wever, The ear and hearing in the frog, Rana pipiens. Journal of Morphology 141: 461-477. Copyright (c) 1973 Wiley-Liss, Inc.

along the middle ear, enters the capsule via a flexible oval window, and exits via a round window.

Frogs are unique in having two separate sets of auditory receptors. The BP is fairly small and simple, while the $\mathrm{AP}$, as its name implies, is confined to amphibians and is larger and more complex anatomically $[1,12]$. The AP is largely sensitive to low frequencies, whereas the $\mathrm{BP}$ is more responsive to high frequencies, even ultrasound. The reason for having two separate auditory papillae is unknown.

A landmark work in frog hearing is The Amphibian Ear published by Wever in 1983 [3]. More recent accounts of the hearing mechanism of frogs can be found in a paper by Schoffelen and colleagues in 2008 [12] and another by Van Dijk and collaborators in 2011 [9]. These works describe how, as with mammalian ears, sound enters via the oval window and leaves by the round window. The major difference is that in mammals the round window opens into the middle ear cavity, whereas in frogs it opens into the top of the mouth, protected by muscle tissue (p.82 of [3]). Inside the frog inner ear there are eight patches of sensory epithelia [12]: three cristae in the semicircular canals (for balance); the utricle (linear acceleration); the lagena (low-frequency vibration); the sacculus and its otoconia (substrate vibration and low-frequency sound); and finally, of course, the amphibian papilla (low-frequency sound) and basilar papilla (high-frequency sound). All are hair cells, with hair bundles projecting from the top of the cell. Deflection of the hair bundle stimulates the cell, a finding with a long history of experimental support [13].
In frogs, therefore, the assumption is made that it is the pressure difference between the oval window and round window which is the primary stimulus, and this causes oscillatory flow of fluid through the system and deflection of hair bundles [12]. Wever [3] describes the situation as one in which the auditory hair cells are stimulated by "fluid surgings" (p. 78).

While there is no doubt that deflection of a hair bundle stimulates a cell [14], the experiments do not eliminate the possibility that hair cells may also be sensitive to other physical stimuli. In particular, a hair cell may also respond to pressure across its cell wall, perhaps via some stretch-sensitive channel. This review and synthesis suggests that the AP and $\mathrm{BP}$ are in fact more sensitive to pressure than displacement. The pressure-sensing hypothesis is able to provide explanations for a number of anatomical anomalies.

It is significant that the sensing cells of frogs are not arranged upon a flexible basilar membrane, as they are in mammals. Instead, cells of the AP and BP are located on stiff cartilage and are tucked away within the amphibian recess and basilar recess [1]. The implication is that, in terms of exciting the cells, there is no bending of a membrane induced by a 'travelling wave'. This supports the idea that the input stimulus could well be the pressure wave which travels at $1500 \mathrm{~m} \mathrm{~s}^{-1}$ through the fluids [9]. In this paper the hypothesis is made that hair cells contain a compressible (i.e., pressure-sensitive) element within their structure which permits the pressure wave to excite a stretch 
receptor in the cell wall. This second mode of stimulation could actually work in conjunction with the bending motion associated with flow, adding to sensitivity. Although direct deflection of a hair bundle alone might provide a small degree of sensitivity, it is suggested that a pressurestimulated cell could elongate (like outer hair cells in mammals do) and in this way indirectly produce greater bending of its hair bundle. The projecting cilia and the stretch receptors are conjectured to form a sensitive feedback loop.

The pressure-sensing model requires that hair cells generate a response to oscillating pressure. However, such a model also provides the basis for a closely related possibility: that hair cells may also give a response to static pressure. The proposition has already been made that the mammalian cochlea is sensitive to static hydraulic pressure [15], and this paper also applies that same principle to frogs, where it provides an explanation for the presence of a unique structure, the operculum.

\section{Operculum}

The oval window of the frog ear contains more than just a stapes: adjacent to it is another movable plate-like structure called the operculum (Figures 2 and 3), which is connected to an opercularis muscle. The operculum is usually comprised of cartilage, not bone (although it can be in some species), but it appears to be very much like a secondary stapes. The inner side of the operculum is in direct contact with perilymph; the other side is connected to the opercularis muscle, which in turn is anchored to the shoulder. Some dynamical function for the operculum is indicated.

This paper postulates that the function of the opercularis system is to control the static hydraulic pressure inside the capsule, the result of which is to precisely regulate the sensitivity of the cochlear amplifier. A direct, instantaneous, and non-neural way of controlling the functional gain of all the enclosed hair cells is a simple and effective way of adjusting hearing sensitivity. The static pressure - the DC pressure - controls the AC gain, broadly similar to the way pressure on an accelerator pedal controls the speed of an engine. Such a pressure-driven system simplifies the labyrinthine arrangement of the frog's otic capsule - in essence it becomes a single fluid-filled compartment - and illustrates an important aspect in which the frog ear and the human ear may be related.

The functional role of the operculum has generated a diversity of views. Wever's classic book [3] discusses some possibilities, which date at least to the beginning of the 20th century. A useful historical overview of the various theories of the operculum has been given by Mason [4], and the major theories are summarised below. The reader is referred to Mason's review for details.

1. Sensing of substrate vibration. An early explanation, initially made over a century ago but still current, is that the forelegs of the frog pick up ground vibrations and transmit them via the opercularis muscle to the inner ear. The frog could then have a dual detection system, picking up air-borne vibrations via the stapes and substrate vibrations via the operculum. The opercularis muscle is considered to be in a constant state of tension when on land, allowing sound transmission through the muscle, although it could relax when the frog is in water. A drawback of the theory is that experimental manipulations of the muscle do not strongly support the idea. For example, severing the muscle mostly produces only small changes, and frogs lying on their backs appear to respond normally despite there being no foreleg contact. In general, other experiments have been largely inconclusive.

2. Restraining stapes movement. Wever [3] suggested that contraction of the opercularis muscles locked the operculum and the stapes together. With the stapes locked in this way, motion of the stapes was restrained, preventing acoustic overload. Later authors have drawn attention to the slow speed of contraction of the opercularis. In most species it is comprised largely of tonic fibres, which although fatigue-resistant are slow to contract and relax. Such lack of speed would not enable fast reactions to sudden sound inputs. Also, the opercularis system is present in frogs which lack tympanum and middle ear, making it difficult to build a coherent picture [16]. However, if the operculum's gain control is exerted hydraulically, it follows that a measurement of tympanic membrane vibration might not be an accurate gauge of sound input to the cochlea. That is, manipulation of the operculum might produce only small changes in stapes vibration amplitude [17] but still have an effect on auditory responses.

3. Augmenting stapes movement. A modification of the previous theory is that by locking the operculum and the stapes together, the effective area of the oval window is increased, magnifying sound input and perhaps improving the sensitivity of the sensing cells within. However, the effects of experimentally manipulating the opercularis muscle are not generally consistent with this idea. Hearing sensitivity at low frequencies is sometimes affected, but at higher frequencies the effects are almost invariably small or negligible, which is not what the model predicts.

4. Pressure buffering. It has been observed that activity of the opercularis muscle coincides with flow of air into the lungs. As air enters the lungs, the eardrums bulge outwards because of connections between the Eustachian tubes and the middle ear cavities. The stapes will then be forced into and out of the otic capsule, prompting Mason's suggestion that the opercularis muscle might be working to counteract this motion (see Figure 3). Others have suggested that the operculum simply stiffens, resisting motion, but Mason and Narins [18] consider it may have a more active role: their view is that the opercularis muscle rhythmically contracts and relaxes in time with breathing in order to regulate the position of the stapes. Their hypothesis is that the opercularis system works to buffer any change in inner ear fluid pressure, changes which will occur during the frog's normal daily activity.

This paper is broadly in keeping with the Mason and Narins proposal, for which there is a range of evidence (see p. 172 of Mason 2006), but here the hypothesis is extended to specify that the regulated pressure directly controls hearing sensitivity. It is proposed that the opercularis system directly controls the gain of sensing cells, an outcome achieved through altering the static hydraulic pressure 


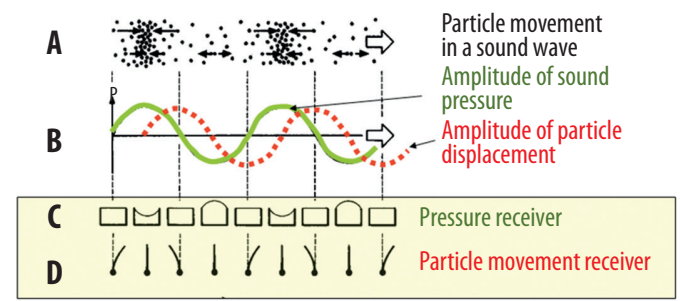

Figure 4. A sound wave has two physical components: pressure and displacement. (A) A sound wave propagating through a medium has regions of enhanced particle density (compression) and diminished density (rarefaction). (B) A plot of variations in pressure (green) and displacement (red). (C) Responses of a pressure detector (such as a microphone diaphragm) to the sound wave. (D) Response of a particle motion detector (such as a stereocilium) to the same sound wave. Adapted from Wehner \& Gehring [23]

surrounding the cells. In this way, the opercularis system acts like the middle ear muscles do in mammals, which regulate sound input to the cochlea via the acoustic reflex. The parallel between frogs and mammals may be even closer: it has been suggested that the middle ear muscles of mammals regulate cochlear sensitivity by adjusting intracochlear fluid pressure [15].

In summary, frogs and mammals both employ static hydraulic pressure to adjust the sensitivity of sensing cells within the cochlea. The following text describes the hypothesis in more detail. The hypothesis is based on recognising a fundamental acoustic property: that an acoustic signal propagating through a medium carries two complementary physical quantities - displacement and pressure. The role of displacement has been widely acknowledged in the literature, but the co-existing variable - pressure has not been generally recognised as a physiological stimulus in its own right. Although the two acoustic variables are related, there is a fundamental difference in the design of a displacement transducer and a pressure transducer, and this provides a new perspective on how the frog ear might operate.

\section{The pressure hypothesis: oscillating acoustic pressure and static regulating pressure}

In air, the displacement component of sound is obvious: sound causes things to vibrate, movement which can even be sensed with the fingertips. However, there is another dimension to sound, as a number of water-dwelling creatures have discovered. Fish detect the pressure component of sound [19], and it is possible that amphibians like frogs do as well. The following section explains how detection of displacement and pressure requires different classes of sensor.

\section{Detecting pressure and displacement}

Based on physical principles, a possible conclusion is that to detect sound in water - as an amphibian must - it is generally easier to detect the pressure component of sound rather than the displacement component. Figure 4 illustrates that a propagating sound wave carries two oscillating components: pressure and displacement. Each physical quantity requires a different kind of detector, as shown in the lower part of the diagram. Detecting the pressure component calls for something like a rigid box filled with compressible material, like air, and covered with a flexible membrane (Figure 4C). A familiar example is a microphone capsule covered with a thin diaphragm which moves in response to the varying pressure difference across it. In contrast, to detect the displacement component, a flexible shaft projecting into the fluid from a solid base is needed, and in biology the cilium provides a good example. Because hair cells have projecting cilia, it has long been thought that most animals hear by detecting the displacement component of sound. However, the presence of a cilium does not rule out that the body of a hair cell could act as a complementary receiver of sound pressure. In fact, since pressure and displacement are complementary variables, both may be involved in sound detection [20-22].

The advantages for detecting the pressure component of sound in water have been set out in earlier publications $[21,22]$. Here, the point is made that a similar strategy provides advantages for the frog ear. It simplifies what appears to be a complex anatomical arrangement, and avoids difficulties associated with detection of displacement.

The reason it is preferable for aquatic animals to detect pressure is that water is nearly incompressible, whereas air, as a gas, is highly compressible. Acoustically, that difference is expressed in terms of acoustic impedance, where the acoustic impedance of water is $1.5 \times 10^{6}$ rayls, while that of air is 3600 times less, 415 rayls. The impedance difference means that, for the same acoustic power, the pressure of a wavefront passing through water is 60 times greater than the pressure of a similar wavefront in air, while the displacement of the particles is 60 times less. Therefore, in water, detection of pressure is physically easier to achieve than detection of displacement $[19,21,24,25]$.

As Figure 4C illustrates, for pressure to be detected, some compressible element is necessary. If any compressible element is immersed in a nearly incompressible liquid, such as water, the system becomes a highly sensitive acoustic detector. If the container enclosing the water is rigid perhaps steel, or for biological systems, bone - then any pressure applied to the water will be instantly transmitted and focused on the most compliant spot - which will be the compressible detector itself. This valuable property was noted by Helmholtz more than a century ago [26], and was appreciated by Békésy [27] who built a model to demonstrate how efficiently underwater sound can be detected (Figure 5).

In the frog ear, the compressible element could be within the detector itself: the hair cell. If the assumption is made that the body of the hair cell contains some highly compressible element, perhaps even air, then when the pressure in the surrounding fluid increases, the hair cell is squeezed and pressure-sensitive channels in the wall of the cell are activated. An alternative model is that the compressible element might reside in the tectorial membrane itself, an idea following from consideration of Figure 6, or 


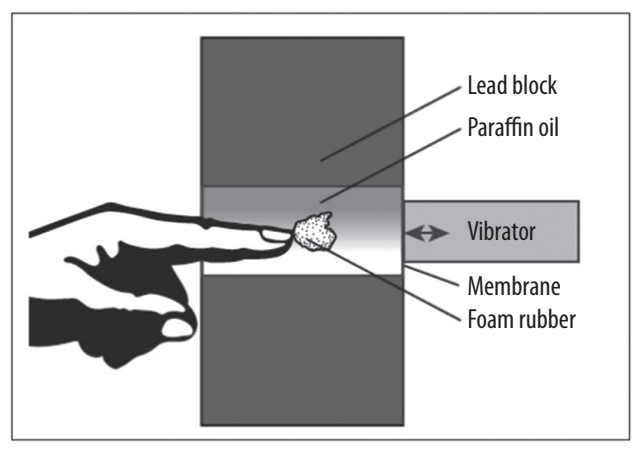

Figure 5. An efficient way to hear underwater, as demonstrated by Békésy [27]. A compressible piece of foam rubber is immersed in incompressible liquid, and enclosed by a lead block and flexible membranes. When a vibrator was applied to one of the membranes, touching the foam produced the sensation of strong vibrations. This arrangement is an ideal model for the otic capsule of the frog. Reproduced from Bell [21]

fill the bulb often visible at the top of the kinocilium, as suggested in ref. [22].

The active process within hair cells arises by two separate mechanisms, one relying on the motility of the hair bundle and the other by the motility of the cell body [28-30]. Either of these processes can provide positive feedback and lead to oscillations and otoacoustic emissions. Which process is used depends upon the species, although both mechanisms are possible within the one animal, and the processes may be interconnected.

Relevant to the pressure detection hypothesis are observations that certain pressure-sensitive channels reside in the basolateral walls of hair cells and that mechanically sensitive proteins, Piezo1 and Piezo2, form huge transmembrane channels which can directly transduce pressure differences across the basolateral wall $[29,31,32]$. At the same time, a puzzling observation is that the transduction channel for sound has still not been identified, despite a search over more than two decades $[29,33]$. An explanation could be that the principal channel resides in the cell wall, not at the tip link.

There are several reasons why, for the frog ear at least, pressure might be the stimulus targeted for transduction. As set out below, the compressibility idea simplifies the mechanics of the frog's otic capsule enormously: the pressure stimulus will automatically find its way to the most compressible elements - the sensing cells - despite a labyrinth of hydraulic pathways [26]. There are two major puzzles for the displacement model: firstly, the frog ear contains a number of hydraulic "short-circuits" which severely attenuate displacement stimuli; secondly, the two auditory sensors, the basilar papilla and the auditory papilla, are located within recesses, apparently protecting them and making it difficult for fluid motion to reach them. In contrast, the pressure-sensing hypothesis requires only that the inner ear be a rigid container of incompressible fluid (like Figure 5). The pressure builds up at the oval window (the flexible membrane at the right of Figure 5), and

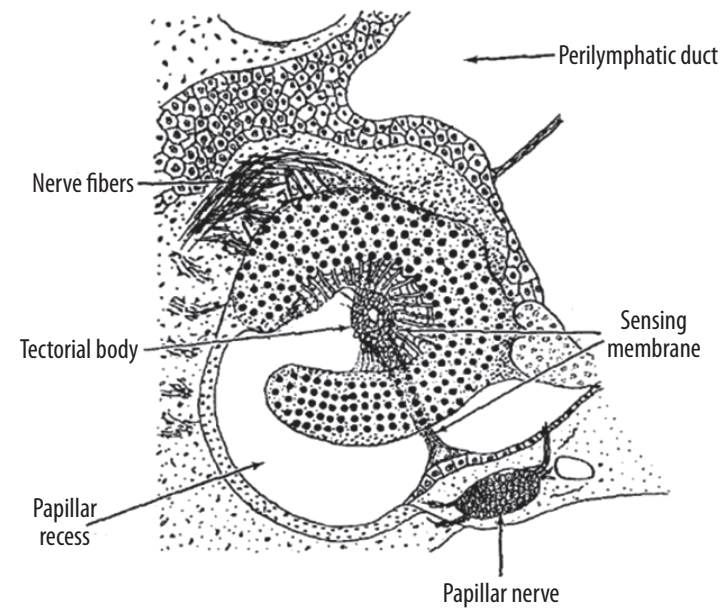

Figure 6. A circle of sensing cells in the papillar recess of the frog, Scaphiopus hurteri. The circular arrangement of the hair cell nuclei (black dots) strongly suggests that the cells are not positioned so as to detect fluid motion in a particular direction. Instead, it appears as if the cells are focused on detecting vibration emanating from the centre of the circle, the middle of the tectorial body. This is a likely location for a compressible element, such as an air bubble, and the drawing, from Wever, is consistent with such an interpretation. The distance between rows of sensing cells ranges from about $15 \mu \mathrm{m}$ at one end to about $30 \mu \mathrm{m}$ at the other. From Figures 6-9 of Wever [3] and used with the permission of Princeton University Press

works against the compliance of the round window (membrane at left). A practically uniform pressure field is thereby built up throughout the capsule, and this pressure is sensed by the AP and the BP (the sensing "finger"). The model matches form and function, and provides a functionally important role for the operculum.

\section{Evidence in favour of the pressure model}

Short circuits, and sensing cells hidden away

Purge and Narins [11] constructed a physical model of how sound energy progresses through the otic capsule of the frog, and their anatomical diagram is shown in Figure 2. The arrows in the diagram show the circuitous pathways taken by sound from oval window to round window, and here attention is drawn to the convention that the arrows represent particle motion as generated by a pressure difference between oval and round windows. More particularly, it is pressure differences across the AP and the BP that are meant to produce fluid displacements and to bend hair bundles. Similarly, in Figure 3, the size and direction of the arrows drawn by Wever signify displacements.

One potentially confusing factor can be put aside. Figures 2 and 3 show that the inner ear is filled with multiple compartments, some filled with perilymph (blue) and other with endolymph (pink). Anatomically, there are only thin membranes separating these two types of fluid, and so these highly compliant membranes cannot resist small 
fluid movements. As in mammals, the membranes act as barriers to preserve chemical and voltage gradients which assist hair cells in producing generator potentials. These thin membranes are effectively transparent to sound [34] and can therefore be disregarded in terms of affecting pressure and flow within the otic cavity.

However, in terms of displacement, there is still a paradox. There are a number of situations in which fluid flow across the papillae is short-circuited by various alternative pathways. The problem, as noted by Purgue and Narins [11], concerns major short-circuiting of the initial fluid displacement produced by the stapes (see Figure 2). The blue line marks the initial displacement of perilymph, and Purgue and Narins note that there are two possible paths for the energy to take. One is straight ahead towards the AP and $\mathrm{BP}$, via the endolymph, which is shown as the continuous line (blue in perilymph; red in endolymph). The other path, however, is through the periotic canal, the path shown as the series of broken blue arrows to the right in Figure 2. As the authors note, "energy traveling down this path does not generate flow through either the AP chamber or the BP recess." It is what Purgue and Narins call a bypass, or hydraulic short-circuit.

Aggravating the problem, there is a second short-circuit once the signal reaches the endolymph. As shown in Figure 3, there is a thin membrane between the saccule and perilymph, a membrane next to which Wever draws a short arrow. Wever [3] notes that "this thin area acts as a bypass and allows some fraction of the fluid motion to go directly into the perilymphatic duct without being detected" (p. 473), and if this were so then, in terms of fluid surgings, a larger arrow would be appropriate, given his comment that thin flexible membranes are practically transparent to sound (p. 470).

Wever draws a large arrow to represent flow past the BP (Figure 3), as though this is the stimulus to the hair cells. However, when the position of the $\mathrm{BP}$ is examined more closely, it is found that the hair cells are placed on the side wall of a duct (the basilar recess) and are covered by tectorial membrane. The rest of the recess's cross-section is unfilled, leaving a large lumen through which fluid might flow almost unhindered. There is now a difficulty, in that Wever's text (p. 473) states that the fluid motions constitute the actual stimulus to the auditory receptors, so that it is essential for the receptors to lie in the path of these motions. He acknowledges (p. 474) that fluid will, to some extent, flow by without having an effect, but it is hard to match such a situation with the need for utmost sensitivity.

Mason et al. [35] agree that this path could act as a bypass. However, their approach is to turn this apparent drawback into a possible advantage by suggesting it could be a way of preventing acoustic overload. Modelling by Purgue and Narins [36] supports this idea by showing that the bypass might act as a protective shunt at low frequencies. However, the modelling did not consider the effects of compressible elements within the otic capsule. More generally, it is difficult to understand why a vibration detector should be arranged to have such a high sensitivity that its operation needs to be compromised in order to avoid overload. A separate gain-control device might be

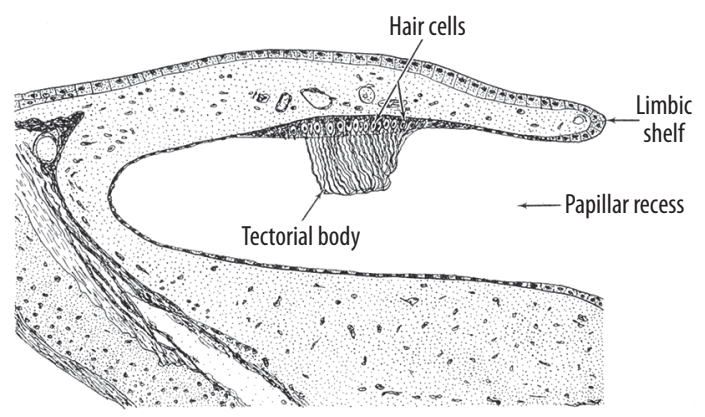

Figure 7. The amphibian papilla is an arrangement of hair cells, covered with tectorial membrane, located on the dorsal wall (top) of the amphibian recess (AR). In this hidden position, interception of fluid flow would be difficult, but detection of hydraulic pressure would not be impaired. From Wever [3] and used with permission of Princeton University Press

more effective, such as the middle ear muscles in the human cochlea. In this way, sensitivity could be usefully retained and only turned down when necessary.

Wever also draws another equally large arrow towards the AP (upper part of Figure 3). Since fluid volume must be conserved, it raises the question of where the fluid goes after it reaches the AP. The AP is located on the stiff limbic wall of the amphibian recess, which, as its name implies, is another cavity located out of the way of direct fluid flow. The placement of the AP within the recess is illustrated in Figure 7, an arrangement which raises questions about how fluid flow could bend hair bundles. The sensory cells are covered with a gelatinous tectorial membrane, which blocks full access to the cavity [9] and appears to offer additional protection to the hair cells. Wever [3] considered that the tectorial membrane itself was excited by sound (forming a so-called sensing membrane), and that vibration of this membrane is then directed to the hair cells. The difficulty now is, if the membrane is not fully across the flow, how can back and forth movement of fluid excite the tectorial membrane? Logically, the expectation is that the hair bundles should be located directly across the fluid path, rather than to one side of the cavity and covered with protective gel.

Even though short-circuits exist within the otic capsule, every parcel of fluid displaced by the stapes assists in building up pressure within it. The fluid within the otic capsule is incompressible, so small displacements of the stapes and operculum will cause an appreciable rise in the internal hydraulic pressure. If the hair cells are pressure sensors, not displacement sensors, the hair cells can be located anywhere within the capsule and complex fluid pathways or internal short-circuits will not affect sensing efficiency. Provided the round window is watertight and the fluid is incompressible, every nanometre of stapes motion will contribute to a build-up of pressure and activation of the sensing cells [34]. Compliance of the round window is the crucial variable which converts stapes displacement into intracavity pressure.

In terms of sensing pressure, having the sensing cells immersed in incompressible fluid and surrounded by rigid 
bone provides an ideal arrangement. Every pressure sensor carries some degree of compressibility, and the higher the compressibility of the material inside a pressure sensor (which can be air, as in an aneroid barometer), the higher will be its sensitivity. As Helmholtz noted, any force applied to a rigid container filled with incompressible fluid will naturally seek out the most compressible element and compress it [26], automatically ensuring that the energy of the input signal is conveyed directly to the sensor. The conclusion, therefore, is that the hair cells of the frog should have a measurable degree of compressibility - a testable prediction.

\section{Like middle ear muscles of mammals}

To this point, attention has focused on how, via a simple hydraulic process, stapes vibrations will be converted into oscillating pressure variations. That same process means that a static displacement of the operculum will produce a static pressure throughout the capsule. In particular, a fixed displacement of the operculum, driven by the opercularis muscle, will lead to corresponding variations in static hydraulic pressure of the otic capsule's fluid contents, with the transfer function between displacement and pressure regulated by the round window compliance. The round window's compliance becomes the all-important master controller of the system.

Why does the frog require the ability to regulate hydraulic pressure within its inner ear? A clue comes from a comparison with the middle ear muscles of humans. In this system, the muscles protect the cochlea from overload, and it has been proposed that the way the middle ear muscles achieve this regulation is by pushing the stapes into the cochlea. Because the fluid contents are incompressible, the hydraulic pressure rises, leading to decreased gain of the sensing cells, in this case the outer hair cells. In the mammalian system, the OHCs are assumed to be pressure sensors, and the interplay between triplets of OHCs creates a standing wave, the amplitude of which defines the gain of the cochlear amplifier [37]. A significant finding is that the human cochlea has a small degree of compressibility [38]. In this model, the AC gain of the cochlear amplifier is regulated by a DC signal, and given the evolutionary connections, a similar system might be found in frogs.

On this basis, the opercularis muscle in the frog may be the equivalent of the tensor tympani in mammals, which pulls inward on the middle ear ossicles and pushes the stapes into the oval window. It has been calculated [15] that when the tensor tympani exerts a force of $1 \mathrm{~g}$ on the oval window, this generates a pressure of $10 \mathrm{kPa}$ within the inner ear fluids, and here it is proposed that a similar outcome comes from activation of the opercularis muscle. If static pressure controls hearing sensitivity, then aberrations in pressure regulation could have major consequences. Maladies such as Ménière's disease and elevated intracranial pressure are associated with abnormal levels of fluid pressure in the cochlea, so the possible effects of static pressure on hearing are understandable. Noting that hearing in water requires different transduction mechanisms than hearing in air $[19,39]$, more fundamental research into the question is needed.
Because frogs are amphibious and need to hear well in both water and air, study of the mechanisms underlying their hearing provides valuable insights. So far as the middle and external ear is concerned, frogs have a diversity of anatomical arrangements, and these complexities - such as the details of their middle ear muscles, including the stapedius - will not be considered here. The focus will be on the action of the opercularis muscle, which all frogs have.

\section{Otoacoustic emissions and pressure sensing}

Van Dijk et al. [9] emphasise how the frog has no basilar membrane and no travelling wave, yet it emits otoacoustic emissions, a situation which confines the range of possible explanatory models. Their preferred model is one in which otoacoustic emissions propagate - in both the forward and backward directions - via fast longitudinal pressure waves (p. 57). The pressure-sensing hypothesis under consideration here is consistent with this model. The alternative view, in which the hair bundles of the AP and $\mathrm{BP}$ react to bending, not pressure, gives rise to two related problems. First, how can bending accurately replicate a fast pressure wave response, and secondly how can a hair bundle generate otoacoustic emissions?

The generation of otoacoustic emission has major implications for the way human hearing works. Is hearing a matter of detecting fast pressure waves or slow traveling waves [40]? A proposal has been made that humans hear by detection of the fast pressure wave $[21,41,42]$, and if it were the case that frog ears also do so - as the analysis here supports - then it is possible that human ears and frog ears are more similar than first thought. Both detect the pressure component of sound, both create otoacoustic emissions with similar properties, and both regulate hearing sensitivity via static hydraulic pressure.

\section{A circle of sensing cells}

In deciding whether pressure sensing or displacement sensing is more effective, an important consideration is that pressure is a scalar quantity, whereas displacement is a vector. When a wave propagates in an open medium, the vector displacements are in the direction of propagation. However, when a wave is confined within a small volume, as it is in the otic capsule, the wave, travelling at $1500 \mathrm{~m} / \mathrm{s}$, will rapidly undergo multiple reflections within the containing fluids. For a structure only a few millimetres long, the wave will have undergone a thousand or more reflections within a millisecond, essentially removing all directional (vectorial) components and leaving just a scalar component, pressure.

To detect this pressure signal, sensors can be placed anywhere within the capsule, since it is not necessary to capture directional information. Consider then a situation where the sensing cells are arranged in a circle (Figure 6). Here, the sensing cells surround a spot in the centre, where there appears to be a hole or inclusion within the tectorial body. This geometry provides an ideal pressure-sensing arrangement in which there is a compressible element at the centre - possibly an air bubble - which oscillates in volume in response to the imposed sound pressure. Schematically, this configuration is the same arrangement 
illustrated in Figure 5. Instead of a finger, there is a circle of hair cells well suited to detecting waves emanating from this oscillating bubble. The wave propagates through the gelatinous tectorial membrane before reaching the cells' stereocilia. With this configuration, pressure-to-displacement conversion takes place outside the cells, not inside.

A circular arrangement of cells would be largely ineffective in detecting the displacement component of a wave traveling from oval window to round window, whereas such an arrangement is ideally placed to sense volume changes caused by pressure oscillations. In addition, the graded variations in row spacing evident in Figure 6 allow tonotopic tuning. The end of the semicircle with the smallest row spacing (at the bottom of the figure) is capable of supporting high frequency standing waves, whereas the other end, with the greatest row spacing (at the top), can support lower frequency standing waves. Sensing cells in amphibians typically exhibit alternating polarity between adjacent cells (e.g. Figure 3b of [9] where the pattern of polarity is shown by the double-headed arrows), a design appropriate for supporting standing waves between active elements [41,42]. A good example of back-to-back cells which could actively create standing waves between matching pairs is shown in [3], where Wever's drawing (his Figure 19-5) depicts all the cells on one side of the AP facing one direction and all the others facing the opposite way. In one specimen of a caecilian (not a frog but nonetheless in the amphibian family), Wever finds 368 hair cells facing one way and 384 the other (p. 442). The system could then be tuned across the mid-line so that there are short, high-frequency standing waves near the centre and long, low-frequency standing waves between the furthermost edges. Vibrational energy could then be sent back and forth between sensing cells, a process not unlike a tennis volley. A similar pattern of alternating polarity has also been discovered in the ears of lizards, and the same explanation has been put forward [41].

If ripples expand from a central point, it is possible for reflection to occur at a boundary and for a standing wave to form. The length between the nodes of the standing wave will depend on the frequency. Standing waves are familiar in all resonating structures such as guitar strings and xylophone bars, and such waves have been put forward as an explanation for otoacoustic emissions in the human cochlea, where the outer hair cells appear in three precisely defined rows [37]. In the human case, the standing waves are possibly based on "squirting waves" (or Krauklis waves), which have slow propagation velocities; if the rows have opposite polarity, whole-wavelength standing waves can form between the rows. In this surface acoustic wave (SAW) model, tuning relies on the microscopic distance between the rows of hair cells, a distance that in humans varies from 5 to $20 \mu \mathrm{m}$. In Figure 6, the distance between cells ranges from about 15 to $30 \mu \mathrm{m}$.

\section{Pressure-to-displacement converters}

In 1982, some experiments gave indications that frog ears were responding to the pressure component of sound, not particle velocity [43]. However, interpretation of this work is complicated because of the difficulty in separating the action of the two sound components. Every compressible volume is effectively a pressure-to-displacement converter, and the experiments cited found that the air-filled middle ear cavity dominated the situation (see also [19] for a discussion which extends to mechanisms of fish hearing). Measuring effects due to compressible elements inside the inner ear (rather than the middle ear) would require more detailed investigation.

A related anatomical oddity is the case of certain species of frogs in which the males grow spongy lumps on their eardrums during the mating season [8]. In analogy with Békésy's piece of foam rubber (Figure 5), if the growths were to contain compressible material like air, then a pressure-to-displacement converter would exist directly on their eardrums. This would help the frogs detect sound underwater, perhaps the calls of other males. Oscillation of the growths in response to sound pressure would vibrate their tympanic membrane and increase the sensitivity of their underwater hearing. The arrangement has a resemblance to modern middle ear implants which overcome conductive hearing losses by driving the ossicular chain directly [44]. At other times of the year, the frogs may benefit more from hearing air-borne sound, meaning the lumps would then be a liability rather than an asset, and the growths would disappear.

In the case of frogs which spend most of their lives in water, there may be no great advantage in hearing air-borne sound at all. This may be the case with "earless" frogs, who are terrestrial frogs which have inner ears but no external tympanum [2]. Instead, the middle ear cavity is filled with loose connective tissue, a perplexing situation which Jaslow and colleagues (p. 70) regard as indicating that the standard impedance matching function of the middle ear is overly simplistic. A relevant consideration here is that, in terms of collecting area, a compressible element in water collects energy within a distance of half a wavelength (several metres at $100 \mathrm{~Hz}$ ), which would make a tympanum unnecessary.

\section{Wever gain control measurements}

This section considers the evidence of direct observations of the operculum. The core hypothesis of this paper is that contraction of the opercularis muscle leads to a change of hydraulic pressure in the otic capsule, and this static pressure is the parameter which controls the sensitivity of the hair cells to sound-induced oscillating pressure. Here evidence is assembled that activation of the opercularis muscle reduces hearing sensitivity.

\section{Wever}

Wever's work [3] provides the most direct evidence in favour of the operculum being a controller of hearing sensitivity. Wever anesthetised Southern leopard frogs and observed sound-evoked inner ear potentials (hair cell microphonics) from an electrode inserted into the frog's otic capsule. His findings were that the microphonics had a distinctive $\mathrm{V}$-shaped frequency response, with a maximum sensitivity at about $1500 \mathrm{~Hz}$. The frequency response had two almost linear portions, one rising steeply towards higher frequencies and another rising more gently towards lower frequencies, a pattern shown in Figure 8. The two linear portions, shown in bold, represent the basic case where 


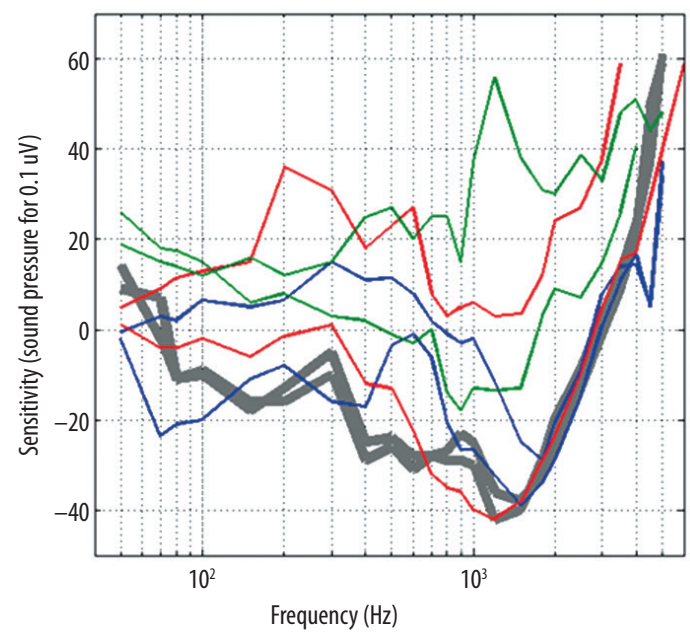

Figure 8. Spontaneous changes in the hearing sensitivity of 4 frogs as measured by Wever [3] from inner ear potentials. Each frog was measured twice, represented by two traces of each colour. There are drastic changes in sensitivity, sometimes by as much as $72 \mathrm{~dB}$, which Wever tracked down to activity of the opercularis muscle. The most sensitive and most reproducible case is outlined with the grey bold lines, which is data from deeply anesthetised frogs where the muscles are presumed inactive; the other lines are from lightly anesthetised frogs with more active muscles. The conclusion is that activity of the opercularis muscle can strongly dampen cochlear sensitivity, that is, the muscle can provide overload protection. Data is replotted from Figures 3-30 to 3-33 of Wever (1985), and the ordinate is sound pressure (0 $\mathrm{dB}=1 \mathrm{dyne} / \mathrm{cm}^{2}=74 \mathrm{~dB} \mathrm{SPL}$ ) required to produce $0.1 \mu \mathrm{V}$

the frog is deeply anesthetised and the opercularis muscle relaxed. However, as anesthesia wears off, Wever observed that the opercularis muscle became active and, significantly, the inner ear potentials in response to sound became much smaller. The key result was that the frog ear's sensitivity to sound could spontaneously change by as much as $72 \mathrm{~dB}$ (4000-fold).

Providing a physical explanation for why the potentials change so markedly is difficult, and Wever was initially puzzled. He describes how it took him several months of investigation, but he finally found that the operculum and its attached opercularis muscle were responsible. The decrease in sensitivity, he suggested, was due to the opercularis muscle becoming active as anesthesia wore off. When it contracts, it tightens an associated ligament which tends to push the operculum into the otic capsule (Figure 3-37 of [3]); according to the pressure model, this motion would increase the hydraulic pressure in the otic capsule. In fact, Wever thought the attenuation was due to mechanical locking between the operculum and stapes, but the pressure model implies, based on consideration of related evidence [15], that the effect results from the way in which hydraulic pressure affects hair cell microphonics. Wever's experiments directly showed that microphonics were affected by muscle tension: when he artificially pulled on the columella and opercularis muscles, the electrical responses systematically increased and decreased (p. 67).
Wever's protection theory was generally not well received, and subsequent experiments by Hetherington presented evidence that did not appear to support it. The experiments focused on measuring the amplitude of vibration of the tympanum, and assumed that tympanum vibrations were, by lever action, directly and passively transformed to sound input to the inner ear. Under this arrangement, the operculum did not seem to govern input sensitivity. However, it is now known that the inner ear is active and nonlinear. Later experiments by Hetherington measured the vibration of the frog's body, its external ear, middle ear, and operculum [17], but with no definite trend. It is possible that varying levels of anesthesia - which Wever found was a key factor - might have prevented consistent trends from emerging. Some measurements of microphonics in alert frogs were made, but a focus on the operculum as a seismic sensor, rather than a gain control element, gave inconclusive results. In addition, holes drilled in the otic capsule to insert electrodes may have been a confounding factor $[45,46]$. Although Wever explicitly notes he resealed holes that were drilled in the otic capsule (p. 27 of [3]), later workers did not always make clear that they did so. For whatever reason, no other work besides Wever's has directly linked motion of the operculum (which might be reinterpreted as pressure) to actual inner ear responses.

One persistent criticism of Wever's protective theory was that the opercularis muscle contains slow tonic fibres, not fast twitch fibres, indicating that the muscle may not be able to rapidly react and introduce sound attenuation through some form of mechanical disarticulation [47]. This criticism presumes that the opercularis muscle has to rapidly modulate the motion of the stapes. But if the muscle's primary action is to increase hydraulic pressure by pressing on incompressible fluids within the capsule, very little motion is required and the pressure can remain elevated for long periods without additional effort, many minutes if necessary. Note that the middle ear muscles in mammals are similarly composed largely of slow tonic fibres, and the general case for pressure control of hearing sensitivity is made in [15].

An issue of interest is whether the motion of the stapes and operculum are independent. For a number of years, Wever and others considered that, because of anatomical proximity, the two structures were physically connected, and to exert a protective effect, the operculum needed to constrain the motion of the stapes, like a brake on a wheel. But if the structures move independently, as later research confirmed $[2,47]$, then the brake idea wasn't feasible, and so a protective function for the operculum was thought unlikely. However, the options increase if the two structures are anatomically and mechanically separate but still interconnected hydraulically. The braking action of the operculum can be mediated through the fluids, and act directly on the hair cells themselves, not on the vibratory chain. In brief, hydraulics could control the gain of the cochlear amplifier and affect inner ear potentials.

Experiments by Hetherington and others [46] have isolated the opercularis system by cutting the muscle or its attached tendon. The result is that there is only a few decibels of difference in the physical motion of the tympanum - not enough to provide protection. But hair cell microphonics 
is a totally different measure to vibration amplitude of the tympanum, or of any other structure in the chain. Protection can still be provided at the sensory cell level, via hydraulics, even when the vibration amplitude of the external tympanum is unchanged. Cutting the opercularis muscle on one side of the frog might also have a limited effect if the opercularis muscle on the other side is still intact - since the ears are connected via a fluid channel. This cross-connection might also be why only small effects of disabling muscle connections to an ear have been seen $[45,46,48]$.

One noteworthy observation which appears to confirm the operculum's function as a pressure regulator is recorded by Wever [3]. He found (this time in a salamander) that manipulation of the operculum and its muscle had bilateral effects, so when he immobilised or loaded one operculum, it resulted in augmented or reduced effects on the other side (pp. 317-321). Given the tight fluid connection between the ears, such bilateral effects are understandable.

\section{Mason}

As touched on earlier, Mason [4] has made the case that the operculum is involved in pressure regulation, but for a different reason. In a 2006 paper he puts forward reasons for believing that the opercularis system is an arrangement for "pressure buffering" the inner ear fluid pressure, since it is somehow necessary to accommodate the obvious bulging of the ear drum whenever the frog breathes, calls, or moves. Since the tympanum is connected directly to the inner ear via the rigid stapes, Mason considers there needs to be some way of stiffening the system to limit extreme motions and pressure spikes. Activity of the opercularis muscle occurs in synchrony with breathing, providing evidence in support of some sort of pressure regulation. However, Mason's model for linking the opercularis with breathing can be extended to directly involve the hair cells. Not only does the opercularis muscle regulate fluid pressure to prevent excessive tympanum excursions, it also regulates hearing sensitivity by lowering the gain of the cochlear amplifier within the hair cells.

\section{Conclusions}

Despite marked anatomical differences between frogs and mammals, the literature surveyed in this paper supports major similarities in the basic way they detect sound. Van Dijk and colleagues have already noted that the cochlea and the amphibian papilla probably share underlying principles [9]. A similar conclusion has been reached by Bergevin and colleagues when comparing otoacoustic emissions [49]. The case made here is that the inner ears of both kinds of animal work on the principle of detecting sound pressure, not sound displacement. The reason is that the pressure component of a sound is larger, and easier to detect, in water than the displacement component, and the inner ears of frogs and mammals are both filled with incompressible fluid, essentially water. In evolutionary terms, of course, human ears derived from creatures who once lived in water, so it follows that humans may retain the same mechanism for detecting sound propagating through water [50].

The proposal is that the frog ear is a pressure detector and that the gain of hair cells in the inner ear is controlled by the operculum via its effect on static hydraulic pressure. The hypothesis offers a way of solving a long-standing puzzle about the role of operculum. It is suggested that Wever's original idea, seen in the context of a hydraulic pressure mechanism, provides an explanation which matches form and function and is consistent with the data.

For many years, the standard view has been that hearing is a matter of sensing displacement. Because hair cells possess stereocilia, and stereocilia are sensitive to deflection [14], the conclusion has been that deflection of hair bundles is the primary, or effective, stimulus for hearing. However, as has been noted $[21,22]$, a sound stimulus applied to a hair cell could also be detected via the cell body itself $[41,42]$. Motion of the hair bundle associated with a pressure stimulus could be generated by internal cell mechanisms, providing a feedback signal to neighbouring hair cells. The whole process could produce a standing wave a mechanically based cochlear amplifier $[37,41,42]$.

Rather than the compressible element being inside the cell, another possibility, raised by consideration of Figure 6, is that it could be outside the cell, perhaps some portion of the tectorial membrane such as the tectorial body. These ideas gain relevance in the light of recent experiments which find that the energy of an oscillating portion of the mammalian basilar membrane is almost (within $1 \mathrm{~dB}$ ) identical to the energy at the stapes [51]. This is consistent with a basic resonance model of transduction, but more difficult to place within a travelling wave model. A resonance approach to hearing may therefore be useful not just for understanding how frogs hear but also broader questions relating to human hearing.

With a focus on displacement, Békésy's traveling wave theory is the dominant model of human hearing. But if the pressure component of sound is the primary stimulus, the traveling wave model is not necessary and the possibility arises that the ear's tuned elements resonate to incoming sound - a model we owe to Helmholtz [52,53]. The resonance approach may contribute to a better understanding of how the human cochlea operates [54], and also how its function may best be mimicked with a cochlear implant [55].

The insights gained from examining the ears of frogs could produce important advances in understanding the hearing of humans and other vertebrates.

\section{Acknowledgements}

This work received support from the Institute of Physiology and Pathology of Hearing, Warsaw, under contract 132/IFPS/2015. Dr Hero Wit provided useful comments on an earlier version. 
1. Capranaca RR. Morphology and physiology of the auditory system. In: Llinas R, Precht W, editors. Frog Neurobiology: A handbook. Berlin: Springer; 1976; p. 551-75.

2. Jaslow AP, Hetherington TE, Lombard RE. Structure and function of the amphibian middle ear. In: Fritszch B, Ryan MJ, Wilczynski W, Hetherington TE, Walkowiak W, editors. Evolution of the Amphibian Auditory System. New York: Wiley; 1988; p. 69-91.

3. Wever EG. The Amphibian Ear. Princeton: Princeton University Press; 1985.

4. Mason MJ. Pathways for sound transmission to the inner ear in amphibians. In: Narins PM, Feng AS, Fay RR, Popper AN, editors. Hearing and Sound Communication in Amphibians. New York: Springer; 2006; p. 147-83.

5. Purgue AP. Tympanic sound radiation in the bullfrog Rana catesbeiana. J Comp Physiol A, 1997; 181: 438-45.

6. Boistel R, Aubin T, Cloestens P, Langer M, Gillet B, Josset P et al. Whispering to the deaf: Communication by a frog without external vocal sac or tympanum in noisy environments. PLOS One, 2011; 6: e22080.

7. Arch VS, Simmons DD, Quinones PM, Feng AS, Jiang J, Stuart BL et al. Inner ear morphological correlates of ultrasonic hearing in frogs. Hear Res, 2012; 283: 70-79.

8. Narins PM, Lewis ER, Purgue AP, Bishop PJ, Minter LR, Lawson DP. Functional consequences of a novel middle ear adaptation in the central African frog Petropedetes parkeri (Ranidae). J Exp Biol, 2001; 204: 1223-32.

9. Van Dijk P, Mason MJ, Schoffelen RLM, Narins PM, Meerenderink SWF. Mechanics of the frog ear. Hear Res, 2011; 273: 46-58.

10. Zwislocki JJ. Auditory Sound Transmission: An Autobiographical Perspective. Mahwah, NJ: Erlbaum; 2002.

11. Purgue AP, Narins PM. Mechanics of the inner ear of the bullfrog (Rana catesbeiana): The contact membranes and the periotic canal. J Comp Physiol A, 2000; 186: 481-88.

12. Schoffelen RLM, Segenhout JM, van Dijk P. Mechanics of the exceptional anuran ear. J Comp Physiol A, 2008; 194: 417-28.

13. Hudspeth AJ, Corey DP. Sensitivity, polarity, and conductance change in the response of vertebrate hair cells to controlled mechanical stimuli. Proc Nat Acad Sci, 1977; 74: 2407-11.

14. Hudspeth AJ, Jacobs R. Stereocilia mediate transduction in vertebrate hair cells. Proc Nat Acad Sci, 1979; 76: 1506-9.

15. Bell A. How do middle ear muscles protect the cochlea? Reconsideration of the intralabyrinthine pressure theory. J Hear Sci, 2011; 1(2): 9-23.

16. Hetherington TE. The effects of body size on the evolution of the amphibian middle ear. In: Webster DB, Fay RR, Popper AN, editors. Evolutionary Biology of Hearing. New York: Springer; 1992; p. 421-37.

17. Hetherington TE. The middle ear muscle of frogs does not modulate tympanic responses to sound. J Acoust Soc Am, 1994; 95: 2122-25.

18. Abdala C. Maturation of the human cochlear amplifier: distortion product otoacoustic emission suppression tuning curves recorded at low and high primary tone levels. J Acoust Soc Am, 2001; 110: 1465-76.

19. Hetherington T. Comparative anatomy and function of hearing in aquatic amphibians, reptiles, and birds. In: Thewissen JGM, Nummela S, editors. Sensory Evolution on the Threshold: Adaptations in secondarily aquatic vertebrates. Berkeley, CA: University of California Press; 2008; p. 183-209.
20. Bell A. Are outer hair cells pressure sensors? Basis of a SAW model of the cochlear amplifier. In: Gummer AW, editor. Biophysics of the Cochlea: From Molecules to Models. Singapore: World Scientific; 2003; p. 429-31.

21. Bell A. Detection without deflection? A hypothesis for direct sensing of sound pressure by hair cells. J Biosci, 2007; 32: 385-404.

22. Bell A. The pipe and the pinwheel: is pressure an effective stimulus for the $9+0$ primary cilium? Cell Biol Int, 2008; 32 : 462-68.

23. Wehner R, Gehring W. Zoologie. $22^{\text {nd }}$ ed. Stuttgart: Georg Thieme; 1990.

24. Denny MW. Sound in air and water: listening to the environment. In: Denny MW, editor. Air and Water: The Biology and Physics of Life's Media. Princeton: Princeton University Press; 1993; p. 190-220.

25. Lewis ER. Appendix: Useful concepts from circuit theory. In: Manley GA, Popper AN, Fay RR, editors. Evolution of the Vertebrate Auditory System. New York: Springer; 2004; p. 367-400.

26. Helmholtz HLFv. The Mechanism of the Ossicles and the Membrana Tympani [translated by J. Hinton]. London: New Sydenham Society; 1874.

27. Békésy Gv. Some similarities in sensory perception of fish and man. In: Cahn PH, editor. Lateral Line Detectors. Bloomington: Indiana University Press; 1967; p. 417-35.

28. Hudspeth AJ. Mechanical amplification of stimuli by hair cells. Curr Opin Neurobiol, 1997; 7: 480-86.

29. Hudspeth AJ. Integrating the active process of hair cells with cochlear function. Nat Rev Neurosci, 2014; 15: 600-14.

30. Amro RM, Neiman AB. Effect of bidirectional coupling on spontaneous oscillations and sensitivity in a model of hair cells. Phys Rev E Stat Nonlin Soft Matter Phys, 2014; 90(5-1): 052704.

31. Marcotti W, Corns LF, Desmonds T, Kirkwood NK, Richardson GP, Kros CJ. Transduction without tip links in cochlear hair cells is mediated by ion channels with permeation properties distinct from those of the mechano-electrical transducer channel. J Neurosci, 2014; 34: 5505-14.

32. Kim KX, Beurg M, Hackney CM, Furness DN, Mahendrasingam S, Fettiplace R. The role of transmembrane channel-like proteins in the operation of hair cell mechanotransducer channels. J Gen Physiol, 2013; 142: 493-505.

33. Fettiplace R, Kim KX. The physiology of mechanoelectrical transduction channels in hearing. Physiol Rev, 2014; 94: 951-86.

34. Wever EG. The ear and hearing in the frog, Rana pipiens. J Morphol, 1973; 141: 461-78.

35. Mason MJ, Segenhout JM, Cobo-Cuan A, Quinones PM, van Dijk P. The frog inner ear: Picture perfect? J Assoc Res Otolaryngol, 2015; 16: 171-88.

36. Purgue AP, Narins PM. A model for energy flow in the inner ear of the bullfrog (Rana catesbeiana). J Comp Physiol A, 2000; 186: 489-95.

37. Bell A, Fletcher NH. The cochlear amplifier as a standing wave: "squirting" waves between rows of outer hair cells? J Acoust Soc Am, 2004; 116: 1016-24.

38. Shera CA, Zweig G. An empirical bound on the compressibility of the cochlea. J Acoust Soc Am, 1992; 92: 1382-88. 
39. Nummela S, Thewissen JGM. The physics of sound in air and water. In: Thewissen JGM, Nummela S, editors. Sensory Evolution on the Threshold: Adaptations in secondarily aquatic vertebrates. Berkeley, CA: University of California Press; 2008; p. 175-224.

40. Bell A. Hearing: travelling wave or resonance? PLoS Biol, 2004; 2: e337.

41. Bell A. Reptile ears and mammalian ears: Hearing without a travelling wave. J Hear Sci, 2012; 2(3): 14-22.

42. Bell A. The cochlea, surface acoustic waves, and resonance. In: Jabbari E, Kim D-H, Lee LP, Ghaemmaghami A, Khademhosseini A, editors. Handbook of Biomimetics and Bioinspiration. Singapore: World Scientific; 2014; p. 719-41.

43. Hetherington T, Lombard RE. Biophysics of underwater hearing in anuran amphibians. J Exp Biol, 1982; 98: 49-66.

44. Zwartenkot JW, Snik AFM, Kompis M, Stieger C. Gain and maximum output of implantable hearing devices in patients with moderate to severe sensorineural hearing loss. J Hear Sci, 2012; 2(3): 35-40.

45. Hetherington TE. Physiological features of the opercularis muscle and their effects on vibration sensitivity in the bullfrog Rana catesbeiana. J Exp Biol, 1987; 131: 189-204.

46. Hetherington TE. Effect of the amphibian opercularis muscle on auditory responses. Fortschr Zool, 1989; 35: 356-59.
47. Hetherington TE, Jaslow AP, Lombard RE. Comparative morphology of the amphibian opercularis system: 1 . General design features and functional interpretation. J Morphol, 1986; 190: 43-61.

48. Lombard RE, Straughan IR. Functional aspects of anuran middle ear structures. J Exp Biol, 1974; 61: 71-93.

49. Bergevin C, Manley GA, Köppl C. Salient features of otoacoustic emissions are common across tetrapod groups and suggest shared properties of generation mechanisms. Proc Nat Acad Sci, 2015; 112: 3362-67.

50. Bell JA. The Underwater Piano: A Resonance Theory of Cochlear Mechanics. PhD thesis, Australian National University, Canberra, 2005.

51. Van der Heijden M, Versteegh CPC. Energy flux in the cochlea: Evidence against power amplification of the traveling wave. J Assoc Res Otolaryngol, 2015; 16: 581-97.

52. Bell A. A resonance approach to cochlear mechanics. PLOS One, 2012; 7: e47918.

53. Bell A, Wit HP. The vibrating reed frequency meter: Digital investigation of an early cochlear model. Peer J, 2015; 3: e1333.

54. Bell A. Resonance theories of hearing: A history and a fresh approach. Acoustics Australia, 2004; 32: 108-13.

55. Skarzynski H, Lorens A, Piotrowska A, Skarzynski PH. Hearing preservation in partial deafness treatment. Med Sci Monit, 2010; 16(11): CR555-62 